\title{
PRAGMATIC LANGUAGE LEVEL IN AUTISM SPECTRUM DISORDERS FROM THE PERSPECTIVE OF SPEECH AND LANGUAGE THERAPY IN THE CZECH REPUBLIC
}

\author{
Kateřina Vitásková \\ Palacký University in Olomouc, Czech Republic
}

\begin{abstract}
The objective is an overview of the partial research outcomes aimed at evaluating the pragmatic level of communication (PCL) in persons with autism spectrum disorder (ASD) from the perspective of speech and language therapy (SLT) in the Czech Republic, where the SLT system is divided into three different sectors bringing specific views on their concept. A partial objective is to highlight the need to create specific SLT diagnostic materials for national-relevant use and outline their concept. It is based on a brief theoretical analysis of the current state of knowledge, and presents the quantitative and qualitative outcomes based on a mixed research design. Partial results confirm the lack of practical SLT's focus on the area of PCL diagnosis in ASD, the lack of relevant diagnostic materials as well as effective options of SLTintervention in PCL of people with (ASD) focusing on selected individually impaired factors.
\end{abstract}

Keywords: autism spectrum disorder; speech and language therapy; pragmatic language level; diagnosis; assessment; special education.

\section{Introduction}

Pragmatic language level, i.e. the level of social application, social utilization of communication skills accentuating social aspects of communication (cf. Lechta, 2003; Newman, 2007; Grigorenko et al., 2003; Wallace, 2008), is preferred and emphasized in the current speech and language therapy (SLT). The above is seen in the emancipation process of the 1990s referring to the so-called pragmatic-linguistic concept in SLT (cf. Lechta, 2011) as well as in the current classification of communication disorders according to ASHA (American Speech-Language-Hearing Association, 1993) that categorizes pragmatics disorders among language disorders featuring disruption of the language function. This fact can also be detected in the new DSM-V (2013) classification, which, in this context, has established a separate group of disorders for inclusion in SLT and associated with pragmatic language disorder (PLD) - social pragmatic communication disorder (SCD, SPCD) or pragmatic language impairment (American Speech and Language Association, 2015). PLL is addressed in more detail by Watzlavick (1999), who cites that the pragmatics of human communication as a science deals in the broader sense with the effects of human communication and its action at the level of behaviour. Disruption of PLL has a significant impact on interpersonal interaction and socialization in the global aspect (Greenspan, Shanker, 2004). 
The objective is an overview of the partial research outcomes aimed at evaluating the pragmatic level of communication in persons with autism spectrum disorder (ASD) from the perspective of speech and language therapy (SLT) in the Czech Republic, where the SLT system is divided into three different sectors bringing specific views on their concept. A partial objective is to highlight the need to create specific SLT diagnostic materials for nationalrelevant use and outline their concept. It is based on a brief theoretical analysis of the current state of knowledge, and presents the quantitative and qualitative outcomes based on a mixed research design. Partial results confirm the lack of practical SLT's focus on the area of PLL diagnosis in ASD, the lack of relevant diagnostic materials as well as effective options of SLT intervention in PLL of people with (ASD) focusing on selected individually impaired factors.

\section{Pragmatic language level in individuals with ASD}

Deficits and striking differences in PLL are characteristic of the diagnostic category of autism spectrum disorders (ASD). The specifics of disruption of this language level are evident already at early age (inpreverbal vocalization); they manifest in the use of gestures (absence of declarative gestures), in a variety of non-verbal communication, and also determine its verbal component and affect the possibilities of communication application (Bondy, Frost 2007, Boyd, 2011). Disorders of pragmatic language level affect all diagnoses falling with in ASD. The research conducted by Ramberg, Ehlers and Nydén (1996) adverts to the fact that pragmatics of communication in people with Asperger's syndrome shows significant specifics disadvantaging social interaction, despite the possible absence of problems affecting the phonetic-phonological language level and active vocabulary. The mentioned experts mapped the presence of differences in vocabulary, comprehension and pragmatics in three heterogeneous probands. The study results suggest that Asperger's syndrome, due to highly functional autism and SLD, provides significantly higher achievements in verbal IQ, which is a reflection of good active vocabulary, verbal memory and imitation abilities in people with this condition, but also of the homogeneously detected deficits in the social aspects of communication, i.e. in the PLL. The PLL as the basal problem in communication skills in individuals with ASD is also mentioned by Howlin (2005); according to this author, the main problem in the vast majority of people with ASD does not consist in the words they use but in the way how they use them. A significant aberration related to interference in functional communication is the lack of reciprocity and mutuality in communication. This is reflected in reduced ability or even inability to listen to communication of other people, absence of joy in conversation, adaptation problems and associated "jumping into speech", disregard for personal zones or adhering to a popular, one-sided focused topic (Howlin, 2005). Inflexible cognitive style and adaptation problems are addressed by 
Jelínková (2009) who also states that the impact of these problems is evident in the inclination for verbal stereotypies, verbal rituals logorhea or the preference for scientific issues and specific themes at the expense of functional communication. Difficulties associated with PLL in people with ASD have a neurobiological basis, which is evident in the results of a study carried out by Tesinget al. (2009). According to the partial results of this research, individuals with ASD (especially people with Asperger's syndrome) show increased activity in right frontal gyrus - Brodmann area 47 (mapped via fMR); according to the authors of the investigation, this is perceived as compensation force rebellar deficits. Differences in the processing of emotional facial expressions were researched by Critchleye et al. (2000 in Koukolík, 2002). In individuals with ASD, the cerebellum area, the middle parts of the limbic system and the temporal cortex were activated differently relative to the intact persons when processing emotionally saturated information. Unlike the control group, persons with ASD did not activate the left amygdala region in the left half of the cerebellum (in ibid.).

\section{Diagnosis and stimulation of pragmatic language level in individuals with}

\section{ASD}

Effective stimulation of PLLis preceded by detailed diagnosis and differential diagnosis of the partial symptoms, which are in a reciprocal relationship with functional use of communication in the social context. PLL can be diagnosed using a variety of methods and procedures, including test materials, interviews, and observation and analysis method focusing on spontaneous speech samples (Jehličková 2012 in Vrbová, 2012). In the Czech Republic, a diagnostic material primarily targeted on the assessment of PLL in individuals with ASD is currently missing. This fact was an incentive for the intention of its creation, which is represented by the planned output of the project titled Pragmatic language level in individuals with autism spectrum disorders, supported by the Grant Academy of the Czech Republic (14-31457S, 2014/2016, researcher: Vitásková), the results of which are discussed in the following part of this paper. For now, we will present some possibilities of diagnosing this language level with references to both domestic and foreign eventualities. Due to the variability and perfuse nature of the symptoms reflecting mainly on impaired communication skills, the diagnosis of PLL should be primarily the role of a speech therapist. Of course, a comprehensive insight into the given area can be created just in the case of interdisciplinary cooperation with a psychologist, psychiatrist or neurologist and a special education teacher (Vitásková \& Ř́hová, 2014).

Mikulajová (2003) states that high-quality diagnosis alsorequires using anamnestic data of the child, analysis of the child's spontaneous expression, observations and interviews. Pragmatics should also be studied together with 
shooting a video, preferably in the child's natural environment (home, school); only then can we objectively capture all signs of the disruption. The general procedure for the diagnosis of impaired development, which can be modified also for the examination of pragmatics, is presented by Bernstein and Tiegermanová (in ibid.). Other auxiliary diagnostic instructions may include the Heidelberg test of speech development (HSET; however, the results are not quite significant due to the lack of Czech standardization (Grimmová et al., 1997). Currently, the research activity of experts participating in the creation of a completely new diagnostic tool called Functional Communication Questionnaire (DFK) (Functional Communication Questionnaire, 2014) is certainly worthy of consideration.

In Slovakia, another example is the test from 1998 called Examination of Functional Communication (VFK) (Cséfalvay \& Demovičová) (Mikudová, 2014). A relatively new and practically conceived publication, focused on diagnosing not only pragmatic language level but also other areas, is presented by a team of authors under the name Diagnostic Domains for Pupils with Impaired Communication Skills, mainly for SPC workers. The material provides assessment of pragmatic language level and specifically also of non-verbal communication in children using a five-stage scale. In the same context, it also lists other ancillary diagnostic materials: the Munich functional developmental diagnosis for children from 0-3 years (1990), Bayley's standardized scale of child development (1983), Kovař́k's developmental screening (1979), and the Vineland adaptive behavior scale - VABS (1965) (Jehličková in Vrbová, 2012, p. 39). Diagnosis of pragmatic language functions is addressed, for example, by the Test of Pragmatic Language (TOPL), Phelps-Terasaki, Phelps Gunn, 1992, as well as by the Test of Language Competence-Expanded Edition, Secord E. (1989) (Čadilová et al., 2012). There are ASD screening techniques that do not lend close focus on pragmatic language level, such as DACH (Children's autistic behaviour) detecting disruption of verbal communication, non-verbal communication and social behaviour, or structured examination using ADOS (Autism Diagnostic Observation Schedule) testing (Thorová, 2006). However, the genesis of evaluation and selection of the most appropriate and pragmaticlinguistically sensitive as well as relatively reliable test confirms that our knowledge of this area is still insufficient. A certain limitation and criticism of TOPL in favour of using CCC-2 test material better reflecting the degree of pragmatic disorders is noted in the study by Volden \& Phillips (2010), for example. Evaluation of children's communication - CCC-2 (Children's Communication Checklist) is a screening of all communication problems, including the identification of pragmatics disorders. The first testisimplemented by a parent or another adult who is in the immediate vicinity of the person with ASD. Evaluation categories include the start and scenario of the speech, the language used, the context, non-verbal communication, repetitive interests, the frequency of speech, the use and understanding of social rules, the ability to 
steer the conversation, understanding humour, etc. Evaluation takes 15 minutes; after this time, the recording sheet is passed on to a specialist who makes the final evaluation (Volden \& Coolican et al., 2008; Reisinger et al., 2011).

Professional, scientific-popular as well as fiction literature focusing on the issues of persons with ASD provides practical guidance that can stimulate the skills vital for seamless communication with the mainstream society. Here, we will present several examples of how each area can be developed (Mikudová, 2014). Disruption of eye contact, quantitatively as well as qualitatively, is

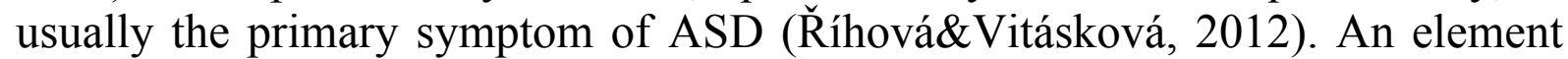
for its mediation may be a verbal instruction, such as "Look at me", along with a reward (gradual modification of the reward into a social reward is necessary) located at the level of the patient's eyes. Another means, already more demanding, is temporary inactivity and silence. Addressing and initiation of conversation should be carried out without undue manifestations or even unpleasant physical touches. Given that people with ASD may have an increased need for tactile stimulation, we can commonly come across inappropriate behaviour and the failure to observe suitable proxemics. For this training, we use role play, group training of social skills or drama lessons (Howlin, 2005). According to Attwood (2008), the positive results of training that focuses on commenting upon the given fact, expressing agreement or disagreement or compliments, are manifested by repeated use of sample situations, picture attachments, etc.

In people with ASD, the inability to express own emotions and recognize feelings in others is a specific and significantly disadvantaging symptom. It is important that persons with ASD are first familiarized with the detailed characteristics of emotions that are to be understood, i.e. they should know what happiness or sadness means, etc. Even in this case, positive results were confirmed when using model situations (through images, photographs, video or audio). The patients describe the phiz of characters, what they experience, how they feel, what caused these emotions, etc. Initially, people with ASD learn to distinguish discrepancies between sadness and joy, and then they select from a wider range of emotions (angry, disgusted, etc.). The basis of functional communication is the development of the ongoing topic of conversation as well as the ability to ask additional questions and show interest in the utterance of the communication partner (Attwood, 2008). Regarding the development of reciprocal conversation, Richman (2008) mentions the following example of utterance of an adult and the answers of a child at play, when walking outside or looking in the mirror.

\section{Methodological aspects of the research}

This part of the paper will introduce the particular results of the research conducted within the project titled Pragmatic language level in individuals with 
autism spectrum disorders (14-31457S, 2014/2016, researcher: Vitásková), supported by the Science Fund of the Czech Republic (GAČR) and implemented at the Institute of Special Education Studies, Faculty of Education, Palacky University in Olomouc.

We will discuss a component part of the research using the method of questionnaire survey as the main research method of choice. The questionnaire consisted of 20 items, predominantly $(n=17)$ having a semi-structured nature. It includes entry information about the research, the assurance of anonymity and final space for any comments and suggestions. During its construction, we preferred the online version made through Google Drive service. The questionnaire was then distributed electronically; contacts of individual respondents, i.e. speech therapists working in the Ministry of Health, Ministry of Education and Ministry of Labour and Social Affairs, were obtained using the online freely accessible e-mail addresses. This mainly relates to the web address of the Association of Clinical Speech and Language Therapists of the Czech Republic, the directory of special education counselling centres for children with communication disabilities; other contacts were found individually.

The questionnaire was distributed on 15 March 2014, and the total number of distributed questionnaires was $745(\mathrm{n}=421$ for clinical speech and language therapists, $n=257$ for speech and language therapists in schools, $n=67$ for speech and language therapists in social resorts).

\section{Research objectives}

In this paper, we focus on the following research objectives:

1. To find whether the addressed respondents perceive the importance of focusing on PLL

2. To analyse whether speech and language therapists in the Czech Republic apply diagnostic tools for PLL in the context of speech and language therapy intervention in individuals with ASD, and to identify what kind of diagnostic materials are involved.

3. To detect communication areas on which speech and language therapists in the Czech Republic subsequently focus in individuals with ASD

\section{Research questions}

The research questions include:

1. Do the addressed respondents perceive the importance of focusing on PLL?

2. Do speech and language therapists in the Czech Republic apply diagnostic tools for PLL in the context of speech therapy intervention in individuals with ASD? What specific materials do they use? 
3. On which communication areas do speech and language therapists in the Czech Republic focus in patients with ASD?

\section{Results of the research}

The first area discussed relates to the question whether the addressed respondents (speech and language therapists in the Czech Republic) perceive the importance of focusing on PLLin individuals with ASD.

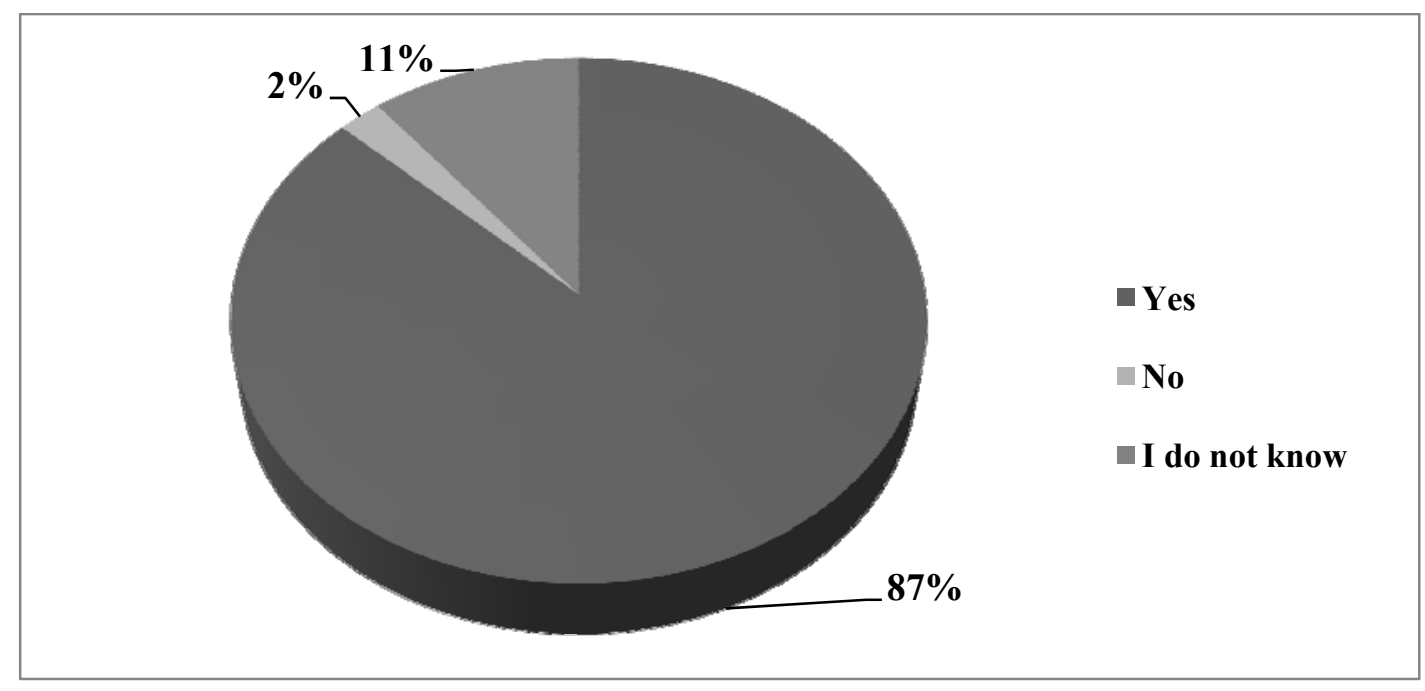

Figure 1. Reflection of the importance of focusing on pragmatic language level in individuals with ASD

Fig. 1 shows that the main representation is of the positive opinion on the diagnosis and stimulation of PLL $-87 \%$ of the respondents. Negative reflection is represented by $2 \%$, i.e. 4 respondents indicate that the diagnosis and stimulation of PLLis not significant. Higher percentage representation appertains to the category of "I do not know", which was chosen by 19 respondents (11\%) and which cannot be seen as negligible; on the contrary, it reveals insufficient awareness of the field.

The answers to this questionnaire item were subsequently justified - see the following selection from individual responses:

R1: "In order to achieve mutual understanding, evaluation of the current abilities to communicate and the communication barriers is necessary. Also, improvements in the quality of life using all means of communication must be applied. The language is essentially worthless to communication without understanding the pragmatic level."

R2:"Because this level is impaired in all people with ASD and because these people are actually not able to communicate, there is a lot of misunderstanding, stress, etc. Within the confidence gained in the successful development of this language level, communication skills might also develop as well as the social self-fulfilment of persons with ASD." 
R3:"It allows us to focus the therapy in a targeted manner and thus develop pragmatic language level. In our practice, there is no time for it, but it is important for life (kindergarten, family, school, etc., should think of it permanently)."

The recorded answers are factually correct and well describe the essence of the importance of focusing on PLL in individuals with ASD. Unfortunately, the negative responses were not properly specified.

The data below relates to areas of communication that are subsequently intervened by speech and language therapists in the context of speech and language therapy intervention in individuals with ASD. Focusing on these areas is also perceived as a reflection of knowledge of the basal language problem in people with ASD, i.e. deficits inPLL, which is also directly associated with recognising the significance of diagnosing PLL in individuals with ASD.

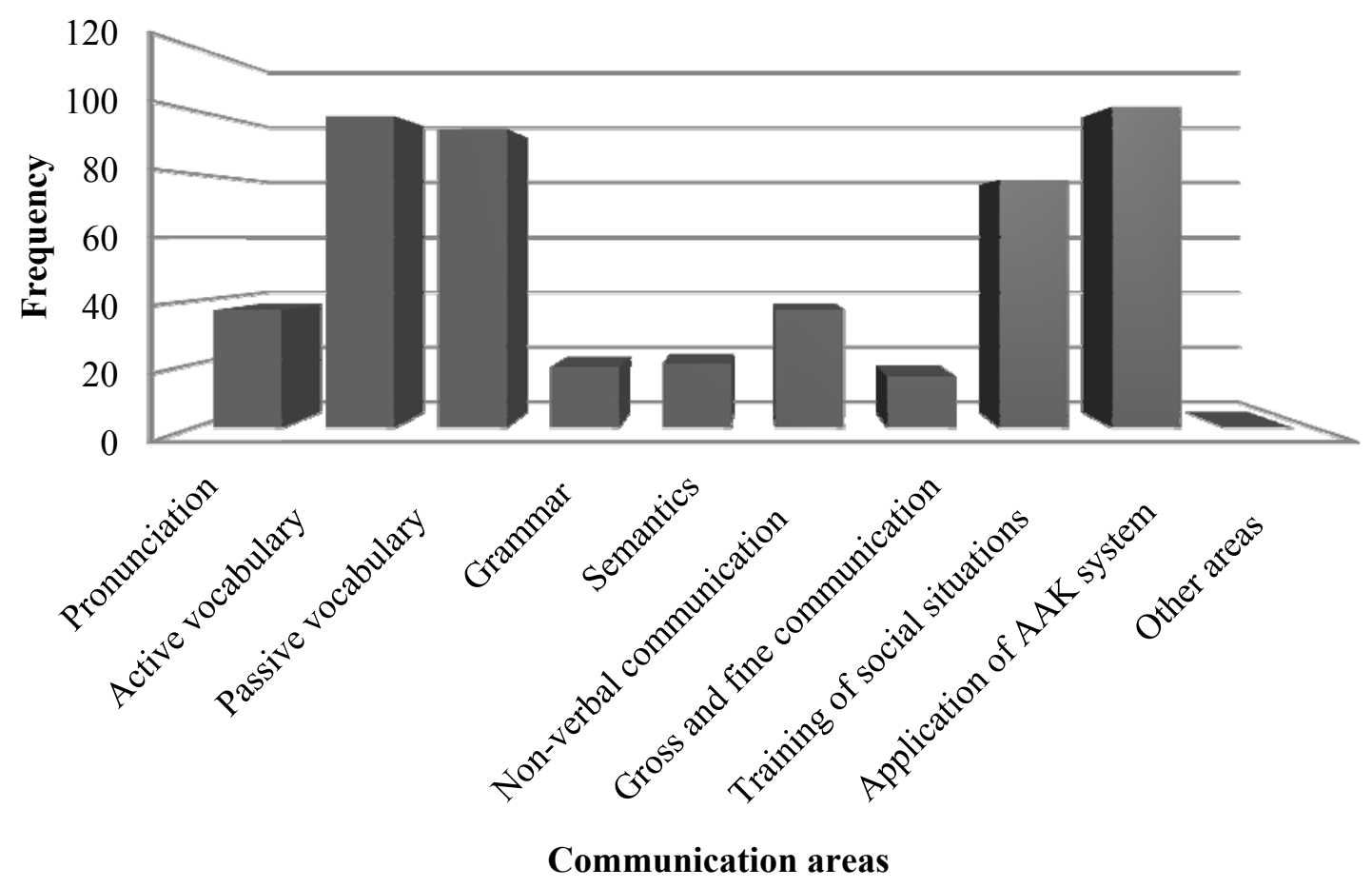

Figure 2. The focus of speech therapists (communication areas)

Fig. 2 shows the areas of communication on which speech and language therapists focus during speech therapy interventions. The results clearly demonstrate that speech and language therapists apply the elements of augmentative and alternative communication at the highest frequency $(\mathrm{N}=101$; $20.2 \%)$. The following positions belong to the development of active vocabulary $(\mathrm{N}=98 ; 19.6 \%)$, the development of passive vocabulary $(\mathrm{N}=94 ; 18.8 \%)$ and training of social situations $(\mathrm{N}=78 ; 15.6 \%)$. When looking at the antagonistic position, the least used speech therapy interventions are those focusing on gross and fine motor skills $(\mathrm{N}=16 ; 3.2 \%)$, grammar $(\mathrm{N}=19 ; 3.8 \%)$, semantics $(\mathrm{N}=20$; $4 \%)$ and pronunciation $(\mathrm{N}=37 ; 7.40 \%)$. 
It is possible to say that we register insufficiently addressed spheres also in the area of targeted development, i.e. those associated with gross and fine motor skills (the respective area was recorded only by 16 respondents). According to the statements of individual respondents, another insufficiently addressed area is the development of grammar, which is critical due to difficulties with generalization and cognitive flexibility. Low frequency saturation is also seen in the case of non-verbal communication, which again represents striking differences in individuals with ASD.

Now we will mention the aspect of reception of communication perceived as impaired in people with ASD by speech and language therapists, and consequently, the diagnostic materials that they apply in individuals with ASD for diagnostic purposes. Knowledge of aberrant language level is the primary prerequisite for properly oriented speech and language therapy interventions and adequately selected intervention content.

Table 1. Reception of impaired communication abilities in individuals with ASD

\begin{tabular}{r|ll} 
Communication area & Frequency & Percentage frequency \\
\hline $\begin{array}{r}\text { Phonetic-phonological } \\
\text { language level }\end{array}$ & 56 & 9.44 \\
Morpho-syntactic language & 74 & 12.48 \\
level & & \\
Lexical-semantic language & 82 & 13.83 \\
level & & \\
Pragmatic language level & 132 & 22.26 \\
Non-verbal communication & 92 & 15.51 \\
Gross and fine motor skills & 34 & 5.73 \\
Oromotor skills & 28 & 4.72 \\
Specifics in visual and & 86 & 14.50 \\
auditory perception & & \\
Other & 1 & 0.17 \\
I do not know & 8 & 1.35 \\
$\mathbf{\Sigma}$ & $\mathbf{5 9 3}$ & $\mathbf{1 0 0}$
\end{tabular}

The above Tab. 1 clearly shows that the area perceived as impaired is mainly that connected with PLL $(\mathrm{N}=132 ; 22.26 \%)$, which can be considered as a positive results ince the deficits in this sphere are typical of people with ASD. PLLis in close reciprocity with non-verbal communication, which was recorded by 92 respondents $(15.51 \%)$. In case of this category, the frequency is already lower but it occupies second frequented position. The following frequency is specific for other variable symptoms that include the specifics of visual and auditory perception $(\mathrm{N}=86 ; 14.50 \%)$, followed by lexical-semantic language level $(\mathrm{N}=82 ; 13.83 \%)$ and morpho-semantic language level $(\mathrm{N}=74 ; 12.48 \%)$.

One of the lowest saturated areas can be considered aberrations in gross and fine motor skills $(\mathrm{N}=34 ; 5.73 \%)$ and the aspect of or motor disorders $(\mathrm{N}=28$; 4.72\%). Despite the fact that these difficulties are detected in the smallest 
numerical representation, we can record them in the context of clinical ASD picture, especially in the diagnosis of Asperger's syndrome or atypical autism, and their presence may complicate the implementation of speech and language therapy intervention and may imply contraindication in the application of intervention procedures requiring fine and precise or motor skills, and gross and fine motor skills.

Regarding the diagnosis of PLL, it is clear that 69 respondents out of the total of 118 speech therapists caring for people with ASD are specifically focused on diagnosing this level. These therapists represent $58.47 \%$, which indicates slightly above-average inclination; however, this cannot be seen as sufficient due to the underlying problems of ASD.

Now, we will specify the diagnostic tools applied in the diagnosis of pragmatic language level in individuals with ASD. In order to map this area, the questionnaire contained an open item in which the interviewees should have noted instruments used for diagnosis of this area of communication. Below, we present some direct statements of the respondents.

R1:"HSET test, I have no other diagnostic materials, own custom modifications, observations, interviews. Non-standard H-S-E-T, also some tests or their parts for aphatic patients, corresponding to age. Without tools, standard questions, situational questions and stories."

R2:"None, evaluation and description of symptoms and traits falling into pragmatic language level. Understanding instructions, images, selection of pictures, scenic pictures, pictures showing some specific situations - greeting, etc."

R3: "Understanding YES-NO sequences, selection of options. I appreciate it as I perceive it. Interview with accompaniment, observations, communication with the patient. Observations, qualitative evaluations. I would examine the level at which the person communicates with his/her close people or strangers, how the person is able to learn, how he/she maintains eye contact, whether he/she use some communication aids, etc."

R4:"PEP-R, I do not know about any. Unfortunately, I have no diagnostic tool; based on indicative logopedicex amination, we assess the area of impaired pragmatic language level (maintaining eye contact, keeping the theme, dialogue, jumping into speech, formal language, informal language, etc.). Observations, interviews with parents, medical history data, games."

These replicas highlight the main problem concerning the absence of diagnostic tests for evaluating PLL in the Czech Republic. This fact is agreed by all of the above presented respondents who point out to this insufficiency and orient themselves in practice mainly based on their own observations or interviews. 


\section{Conclusion}

The presented questionnaire survey is a partial outcome of the GAČR project (14-31457S, 2014/2016, researcher: Vitásková) where the central focus is on pragmatic language level in individuals with autism spectrum disorders (ASD). The reason for choosing this issue is ASD topicality, reflected in the increasing prevalence of people with ASD, in the increased costs of VZPby $21 \%$ (the biggest health insurance company in the Czech Republic) and preferred integration and inclusive trend in special education. A prominent and specific symptom determining the psychosocial development of children with ASD and their subsequent education as well as work self-fulfilment is represented by deficits affecting communication skills, primarily the pragmatic language level.

The central sphere of investigation is the issue of diagnosis. If we look at communication areas diagnosed in persons with ASD in the context of speech and language therapy intervention, they primarily include active vocabulary $(15.90 \%)$ and passive vocabulary (15.61\%). Other positions comprise pronunciation (15.03\%) and training of social situations (15.03\%). One thing is clear: although focusing on pragmatic language levelis considered significant by $87 \%$ of the addressed respondents, in practice they still focus primarily on active vocabulary, passive vocabulary and pronunciation, i.e. the phoneticphonological language level. Furthermore, it is obvious that only $40 \%$ of the respondents apply specific diagnostic tools for evaluating communication disorders in individuals with ASD; specifically, only 58\% of the respondents focus on the diagnosis of pragmatic language level whereas the individual responses show that these respondents advert to the absence of diagnostic material directed at PLL in individuals with ASD, and in practice primarily prefer their own observations or interviews. When implementing speech and language therapy intervention, the speech and language therapists mostly use aids related to alternative and augmentative communication, the so-called classic image materials ommonly available in speech and language therapy workplaces and speech therapy software programmes. Regarding the specific materials applied in the context of intervention, we may mention the TEACCH programme, VOKS, PECS, material obtained within the course completed in APLA Prague and the publication Speech and language therapy intervention in individuals with autism spectrum disorders (Říhová \& Vitásková, 2012).

\section{References}

Attwood, T. (2008). The complete guide to Asperger's syndrome. London: Jessica KingsleyPublishers.

Bondy, A., \&Frost, L. (2007). Vizuální komunikační strategie v autismu. [A Picture's Worth: PECS and Other Visual Communication Strategies in Autism]. Praha: Grada.

Boyd, B. (2011). Výchova ditěte s Aspergerovým syndromem. [Parenting a Child with Asperger Syndrome]. Praha: Portál. 
Čadilová, Z., Thorová, K., Žampachová, Z. a kol. (2012). Katalog posuzování míry speciálnich vzdělávacich potřeb, část II.Diagnostickédomény pro žáky $s$ poruchamiautistickéhospektra.[Catalogue for assessing the degree of special educational needs, Part II. Diagnostic domains for pupils with autistic spectrum disorders]. Olomouc: UniverzitaPalackého v Olomouci.

Cséfalvay, Z.,Lechta, V. a kol. (2013). Diagnostikanarušenékomunikačníschopnosti $u$ dospělých. [Diagnosis of communication disorders in adults]. Praha: Portál.

Dotazníkfunkcionálníkomunikace (DFK). (2013). FakultnínemocniceBrno. [Questionnaire of functional communication (QFC)]. [cit. 2014-04-06]. Retrieved from http://www.fnbrno.cz/nemocnice-bohunice/neurologicka-klinika/dotaznik-funkcionalnikomunikace-dfk/t4546.

Ehlers, S., Nydén, A., Johansson, M., Gillebg, CH. (1996). Language and pragmaticfunctions in school-agechildren on theautismspectrum. International JournalofLanguage\&CommunicationDisorders. 31, (4), 387-413.

Greenspan, S. I.,Shanken, S. G. (2004). Der erstegedanke. Frühkindliche KommunikationunddieEvolutionmenschlichenDenkens. [The first thought. Early childhood communication and the evolution of human thought]: Beltz.

Grigorenko, E.,Klin, A, Volkmar, F. (2003). Hyperlexia: disability or superability? Journal of Child Psychology and Psychiatry, 44, 1079-1091.

Grimmová, H., Schöler, H., \&Mikulajová, M. (1997). Heidelbergský test vývoje řeči H-S-E-T. 2. Brno: Psychodiagnostika. [Heidelberg test of speech development H-S-E-T. 2. Brno: Psychodiagnosis.]

Howlin, P. (2005). Autismus udospívajících a dospělých. Praha: Portál. [Autism in adolescentsandadults]

Jelínková, M. (2009). Vzdělávání a výchova dètí s autismem.[Training and education of children with autism. Prague: IPPP]. Praha: IPPP.

Koukolík, F. (2002). Lidský mozek: funkčni systémy, normy a poruchy. [The human brain: Functional systems, standards and disorders]. Praha: Portál.

Lechta, V. a kol (2011). Terapienarušenékomunikačníschopnosti. [Therapy of impaired communication skills. Prague: Portal]. Praha: Portál.

Lechta, V. a kol. (2003). Diagnostikanarušenékomunikační schopnosti. [Diagnosis of impaired communication skills]. Praha: Portál.

Mikudová, H. (2014). Pragmatická jazyková rovina u osob s poruchami autistického spektra. [Pragmatic language level in individuals with autism spectrum disorders]. Olomouc. Diplomová práce. Supervisor: Ríhová.

Mikulajová, M. (2003). Diagnostikanarušenéhovývojeřeči.[Diagnosis of impaired speech development]. In Lechta, V. et. al. Diagnostikanarušenékomunikačníschopnosti. Diagnosis of impaired communication skills]. Praha: Portál.

Newman, T. M., Macomber, D., Naples, A. J., Babitz, T, Volkmar, F., Grigorenko, E. L. (2007). Hyperlexia in children with autism spectrum disorders. Journal of Autism and Developmental Disorders. 37(4), 760-74.

Reisinger, L., Cornish, K., \& Fomboone, E. (2011). Diagnostic Differentiation of Autism Spectrum Disorders and Pragmatic Language Impairment. Journal of Autism \& Developmental Disorders. 41 (12), 1694-1704

Richman, S. (2008). Výchovadětí s autismem: aplikovanábehaviorálníanalýza.[Raising a child with autism: A guide Applied Behavioural Analysis]. Praha: Portál.

Ríhová, A.,Vitásková, K. (2012). Logopedickáintervence u osob s poruchamiautistickéhospektra. Odbornápublikace pro logopedy. [Speech language and lantherapy intervention in individuals with autism spectrum disorders. Professional 


\section{SOCIETY. INTEGRATION. EDUCATION. Volume III}

publication for speech and language therapists]. Olomouc: UniverzitaPalackého v Olomouci. WOS:000329385700011

Social Language Use (Pragmatics).(2015). cit. [2015-1-14]. AmericanSpeech-LanguageHearing Association ASHA. Retrieved from http://www.asha.org/public/speech/ development/pragmatics.htm

Tesing, C. M. J., Buitelaar, J. K, Petersson, K. M. (2009). cit. [2013-12-19]. Neural correlates of pragmatic language comprehension in autism spectrum disorders. Dostupné $\mathrm{z}$ : http://brain.oxfordjournals.org/content/132/7/1941.short.

Thorová, K. (2006). Poruchy autistického spektra.[Autism spectrum disorder]. Praha: Portál.

Vitásková, K., Ř́hová, A. (2014). Trans-disciplinary Cooperation in Children with Autism Spectrum Disorder Intervention with Emphasis on the Speech and Language Therapist's Important Role. Procedia Social and Behavioral Sciences.132, 310-317

Volden, J., Phillips, L. (2010). Measuring pragmatic language in speakers with autism spectrum disorders: Comparing the children's communication checklist--2 and the test of pragmatic language. American Journal of Speech-Language Pathology. 2010, 19 (3), 204-212.

Volden, J., Coolican, J., Garon, N., Whote, J.,Bryson, S. (2008). Brief Report: Pragmatic Language in Autism Spectrum Disorder: Relationships to Measures of Ability and Disability.[cit. 2014-04-05]. Journalo Autism and Developmental Disorders, 39(2), 388-393 Retrieved from http://eds.a.ebscohost.com/eds/detail?vid=2\&sid=d6c901d2e5a1-48bb-af67-a\%40sessionmgr4001\&hid=4213\&bdata=Jmxhbmc9Y3Mmc210ZT11Z HMtbG12ZQ\%3d\%3d\#db=edselc\&AN=edselc.2-52.0-58549115047.

Vrbová, R. et al. (2012). Katalog posuzování míry speciálních vzdělávacích potřeb. Část II. (Diagnostické domény pro žáky s narušenou komunikačni schopností). [Catalogue for assessing the degree of special educational needs, Part II. Diagnostic domains for pupils with impaired communication skills]. Olomouc: Univerzita Palackého $\mathrm{v}$ Olomouci. Wallace L.G. (2008). Neuropsychological studies of savant skills: Can they inform the neuroscience of giftedness? Roeper Review, 30, 229-246. 